\title{
STRUKTUR KOMUNITAS MANGROVE DI DESA LESAH, KECAMATAN TAGULANDANG, KABUPATEN SITARO
}

\author{
(Mangrove Community Structure at Lesah Village, Sub-District of \\ Tagulandang, District of Sitaro)
}

\section{Indra Asman ${ }^{1 \star}$, Calvyn F. A. Sondak ${ }^{1}$, Josian N.W. Schaduw ${ }^{1}$, Deislie R.H. Kumampung ${ }^{1}$, Medy Ompi ${ }^{1}$, Haryani Sambali ${ }^{2}$}

1Program Studi IImu Kelautan, FPIK UNSRAT Manado.

2Program Studi Budidaya Perairan, FPIK UNSRAT Manado.

*e-mail : Indraasman@gmail.com

\begin{abstract}
Mangroves are forests that grow in brackish water, and are affected by tides and seawater, and these forests grow specifically in places where there is pavement and accumulation of organic material. The purpose of this research is to identify the types of mangroves and determine the structure of the mangrove community in Lesah Village. This research was conducted from September to October 2019. The method used in this research is the quadrant line transect method. The types of mangroves were identified with identification books. Community structure data taken are density, frequency, dominance and important value index (IVI) and then analyzed with Microsoft Excel program. Based on the results of the research, there are 2 types of mangroves found in the research location, Rhizophora stylosa and Sonneratia alba. The highest density value $(0.122$ ind / $\mathrm{m} 2)$, relative density $(81.88 \%)$, frequency types (1), relative frequency $(50 \%)$. Closure types $(1.83 \mathrm{~m} 2)$, types of relative closure $(50.18 \%)$, the highest important value index at the research site was $(182.12 \%)$. The results of the mangrove ecological index data analysis for the diversity index value (0.51), dominance (0.73).
\end{abstract}

Keywords : Structure Community, Mangrove, Lesah Village.

\begin{abstract}
Abstrak
Mangrove adalah hutan yang tumbuh di air payau, dan dipengaruhi oleh pasang surut air laut dan hutan ini tumbuh khususnya di tempat-tempat di mana terjadi pelumpuaran dan akumulasi bahan oraganik. Tujuan dari penelitian adalah mengidentifikasi jenis-jenis mangrove dan mengetahui struktur komunitas mangrove di Desa Lesah. Penelitian dilaksanakan dari September-Oktober 2019. Metode yang digunakan adalah metode line transek kuadran. Jenis-jenis mangrove di identifikasi dengan bantuan buku identifikasi. Data struktur komunitas yang di ambil adalah kerepatan, ferkuensi, dominasi dan indeks nilai penting(INP) dan kemudian di analisa dengan bantuan program computer Microsoft Excel. Berdasarkan hasil penelitian terdapat 2 jenis mangrove yang terdiri dari, Rhizophora stylosa dan Sonneratia alba. Nilai kerepatan tertinggi $(0.122$ ind $\left./ \mathrm{m}^{2}\right)$, kerapatan relatif jenis $(81.88 \%)$, frekuensi jenis (1), frekuensi relatif jenis $(50 \%)$. Penutupan jenis $\left(1.83 \mathrm{~m}^{2}\right)$, penutupan relatif jenis $(50.18 \%)$, indeks nilai penting tertinggi dilokasi penelitian adalah (182.12\%). Hasil analisis data indeks ekologi mangrove untuk nilai indeks keanekaragaman (0.51), dominasi(0.73).
\end{abstract}

Kata Kunci: Struktur Komunitas, Mangrove, Desa Lesah. 


\section{PENDAHULUAN}

Indonesia memiliki luas mangrove yang paling tinggi, yaitu $3,112,989$ ha atau $22.6 \%$ total luas mangrove dunia bahkan jauh lebih tinggi dibandingkan dengan Australia (7.1\%) dan Brazil (7.0\%) (Giri, dkk. 2011 dalam Dharmawan dan Pramudji, 2014). Spesies mangrove yang ditemukan di wilayah Indonesia termasuk dalam dua kelompok wilayah biogeografi belahan bumi bagian timur yakni: Indo-Malesia dan Asia, Australasia dan Pacific Barat (Duke, dkk. 1992 dalam Djamaludin, 2018). Di kedua wilayah ini jumlah spesies mangrove tercatat paling sedikit 57 spesies, termasuk hibrida ptatif. Catatan lainya menurut (Gieasen dkk. 2006 dalam Djamaludin, 2018) jumlah spesies di Indonesia paling sedikit 48 jenis. Jumlah ini termasuk yang paling banyak di Asia Tenggara. Hingga kini, diperkirakan semua spesies mangrove di Indonesia telah terkoleksi tetapi kelemahan mendasar terjadi pada proses identifikasi dan publikasi hasil koleksi spesimen. Salah satu provinsi yang memiliki jumlah spesies mangrove yang tinggi adalah Provinsi Sulawesi Utara.

Menurut (Karauwan, 2011 dalam Paputungan, $d k k$. 2017) data kajian komunitas mangrove di Sulawesi utara bahwa hutan mangrove Sulawesi Utara sekitar 28.000 hektar dan ditemukan 17 jenis mangrove dari 9 famili dimana jenis yang dominan ditemukan adalah Rhizophora, Bruguiera dan Sonneratia. Salah satu daerah yang ada di Sulawesi
Utara yang memiliki kawasan mangrove adalah daerah Desa Lesah, Kecamatan Tagulandang Kabupaten Sitaro. Kawasan mangrove yang ada di Desa Lesah Kecamatan Tagulandang Kabupaten Sitaro terdapat pemukiman warga berjarak 10 meter dari kawasan mangrove dan biasanya dimanfaatkan oleh masyarakat di desa tersebut sebagai tempat penambatan perahu dan juga di manfaatkan sebagai kayu bakar. Tujuan dari penelitian untuk mengetahui struktur komunitas mangrove yang berada di Desa Leash, Kecamatan Tagulandang, Kabupaten Sitaro. Mengetahui indeks ekologi komunitas mangrove keanekargaman dan dominasi. Sendangkan manfaatnya memperkaya pengetahuan dalam bidang ilmu kelautan, khususnya informasi tentang jenis dan struktur komunitas mangrove di Desa Lesah.

\section{METODE PENELITIAN}

\section{Tempat dan Waktu Penelitian}

Lokasi penelitian dilaksanakan di Desa Lesah, Kecamatan Tagulandang, Kabupaten Sitaro, Sulawesi Utara pada titik koordinat $2^{\circ} 21^{\circ} 54.33^{\prime \prime} \mathrm{N}$, $125^{\circ} 22^{\circ} \quad 16.62^{\circ} \mathrm{E}$. Penelitian ini dilaksanakan selama dua bulan. Selanjutnya peta lokasi hasil penelitian ditampilkan pada Gambar.1 


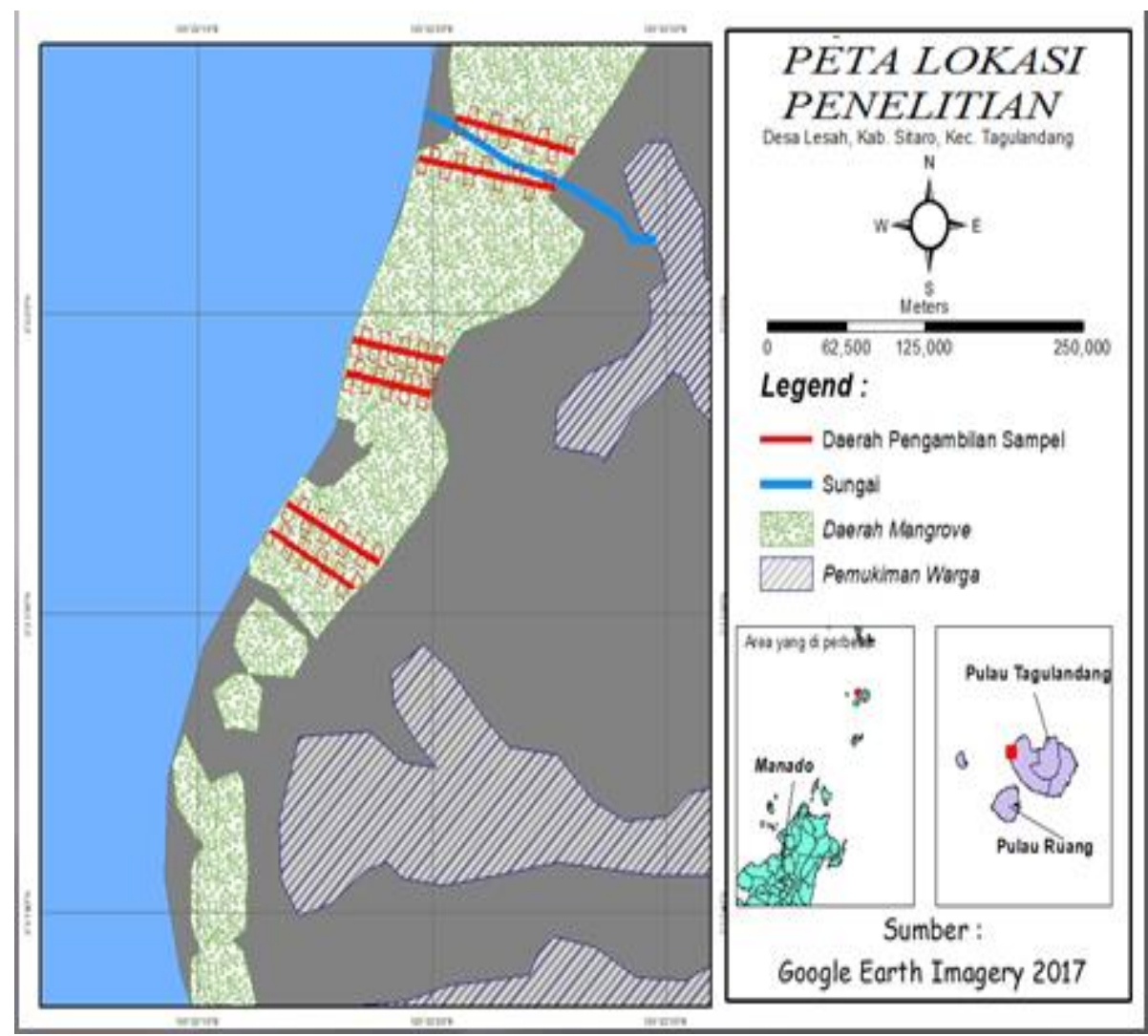

Gambar 1 : Peta Lokasi penelitian

\section{Alat dan Kegunaan.}

Tabel 1. Alat Berserta Kegunaan

\begin{tabular}{|l|c|c|}
\hline No. & Alat & Kegunaan \\
\hline 1. & $\begin{array}{c}\text { Buku Indentifikasi } \\
\text { Mangrove }\end{array}$ & $\begin{array}{c}\text { Pedoman indentifikasi jenis-jenis } \\
\text { mangrove }\end{array}$ \\
\hline 2. & $\begin{array}{c}\text { Global Positioning System } \\
\text { (GPS) Hp J2 Prime 2016 }\end{array}$ & Mengetahui titik koordinat lokasi \\
\hline 3, & $\begin{array}{r}\text { Kamera digital HP J2 } \\
\text { Prime 2016 }\end{array}$ & Mendokumentasikan Penelitian \\
\hline 4. & Tali Plastik & Membentuk kuadran \\
\hline 5. & Alat tulis Menulis & Mencatat data hasil pengukuran \\
\hline 6. & Meteran 100m & Pembuatan line transek \\
\hline
\end{tabular}




\section{Teknik Metode Pengambilan Data}

Pengambilan data struktur komunitas mangrove ini dilakukan dengan metode line transek kuadran dimana terdiri atas tiga stasiun. Dalam setiap stasiun terdapat dua line transek kuadran. Stasiun pertama terletak pada daerah yang berdekatan dengan pemukiman warga, stasiun kedua terletak pada daerah kawasan mangrove dan stasiun ketiga terletak pada daerah muara sungai. Penarikan line transek ini dilakukan pada saat air surut dengan cara menarik line transek sepanjang $100 \mathrm{~m}$ dari arah laut ke darat.

\section{Analisa Data}

Identifikasi vegetasi mangrove menggunakan buku (Kitamura, dkk. 1997 dan Noor, dkk. 2006 dalam Schaduw, 2015). Analisis vegetasi mangrove mempunyai tujuan untuk mendapatkan Indeks Nilai Penting (INP) yang merupakan penjumlahan dari frekuensi relatif, kerapatan relatif, dan dominansi relatif. Nilai penting suatu jenis berkisar antara 0 sampai 300. Nilai penting ini memberikan gambaran mengenai pengaruh atau peranan suatu jenis tumbuhan mangrove dalam komunitas mangrove, untuk ketiga komponen INP tersebut dapat dihitung dengan rumus sebagai berikut :

$$
\begin{aligned}
& D_{i}=\frac{n i}{A} \\
& D i=\text { kerapatan spesies ke } \mathrm{i} \\
& n i=\text { jumlah total individu spesies ke } \\
& \mathrm{i}=\text { luas area total pengambilan } \\
& A \quad \text { contoh }
\end{aligned}
$$

$R D i=\left(\begin{array}{c} \\ \frac{n_{1}}{n} \\ \sum_{i-1}^{n} n_{i} \\ i-1\end{array}\right) \times 100$

$(R D i)=$ Kerapatan relatif spesies ke i

(ni) = Jumlah individu Spesies ke i

$$
F_{i}=\frac{P_{i}}{n}
$$

$\mathrm{Fi}=$ Frekuensi spesies ke $\mathrm{i}$

$\mathrm{Pi}=$ Jumlah petak contoh dimana ditemukan spesies ke i

$R F_{i}=\left(\begin{array}{c} \\ \frac{F_{i}}{n} \\ \sum F_{i} \\ i-1\end{array}\right) \times 100$

$R F i=$ Frekuensi relatif spesies ke $\mathrm{i}$

$F i=$ Frekuensi spesies ke $\mathrm{i}$

$C_{i}=\frac{\begin{array}{c}n \\ \sum B A \\ i=1\end{array}}{A}$

$\mathrm{BA}=\pi \mathrm{DBH}^{2}: 4$ (dalam $\left.\mathrm{Cm} 2\right)$

$\pi=$ konstanta $(3,14)$

$\mathrm{DBH}=$ diameter pohon dari jenis ke $\mathrm{i}$ $\mathrm{A}=$ luas area total pengambilan contoh (luas total petak/plot/kuadrat) $\mathrm{DBH}=\mathrm{CBH} / \pi$ (dalam Cm), DBH adalah lingkaran pohon setinggi dada 


$$
R C_{i}=\left(\begin{array}{c} 
\\
\frac{c_{i}}{n} \\
\sum c_{i} \\
i-1
\end{array}\right) \times 100
$$

$\mathrm{RCi}=$ Penutupan relatif spesies dan luas total area

$\mathrm{Ci}=$ Luas area penutupan spesies ke i

Jumlah nilai kerapatan relatif spesies (RDi), frekuensi relatif spesies (RFi) dan penutupan relatif spesies (RCi) menunjukkan Nilai Penting Spesies (IVi) :

$I V i=R D i+R F i+R C i$

\section{- Indeks Keanekaragaman}

$H^{\prime}=-\sum_{i-1}^{s} P i \ln P i$

$H^{\prime}=$ Indeks keanekaragaman Shannon-Wiener

$\mathrm{N}=$ Jumlah total individu dalam komunitas $\left(\sum n i\right)$

$\mathrm{ni}=$ Jumlah individu spesies atau jenis ke-i

$\mathrm{Pi}=$ Proporsi individu spesies ke-i (ni/N)

$i=1,2,3, \ldots \ldots, s$

Berdasarkan hasil penelitian yang dilakukan pada ketiga stasiun ditemukan 2 spesies mangrove yaitu Rhizophora stylosa dan Sonneratia alba yang termasuk dalam famili Rhizophoraceae dan

Sonneratiaceae. Rhizophora stylosa memiliki ciri-ciri yaitu pohon dengan satu atau banyak batang, tinggi hingga $10 \mathrm{~m}$, kulit kayu halus dan berwarna abu-abu hingga hitam, daun berbentuk elips melebar dengan ujung meruncing, memiliki $s=$ Jumlah genera

\section{- Dominasi}

Untuk menghitung dominasi jenis mangrove digunakan Indeks (Simpson dalam Krebs,1989 dalam Schaduw, 2015) yang dihitung dengan persamaan berikut :

$D=\sum_{i-1}^{s}(P i)^{2}$

$\mathrm{D}=$ Indeks Dominasi

$\mathrm{Pi}=\mathrm{ni} / \mathrm{N}$

$\mathrm{ni}=$ Jumlah individu spesies ke-i

$\mathrm{N}=$ Jumlah total individu semua spesies

$i=1,2,3, \ldots \ldots ., s$

$\mathrm{s}=$ Jumlah genera

Nilai $D$ berkisar antara $0-1$

(Odum, 1971 dalam Schaduw, 2015 ). Jika nilai $D$ mendekati 0 , berarti hampir tidak ada individu yang mendominasi, dan jika nilai D mendekati 1, berarti ada salah satu genus atau spesies yang mendominasi.

\section{HASIL DAN PEMBAHASAN}

Jenis-jenis Mangrove di Desa

Lesah.

buah berbentuk seperti buah pir berwarna coklat, dan memiliki akar tunjang dengan panjang hingga $3 \mathrm{~m}$. Jenis mangrove Sonneratia alba memiliki ciri-ciri kulit kayu berwarna putih tua hingga coklat, memiliki akar nafas, daun berbentuk bulat telur terbalik dengan ujung membundar, dan buah berbentuk seperti bola. Bentuk daun, bunga, dan buah dari spesies Rhizophora stylosa dan Sonneratia alba (Noor, dkk.2006). 


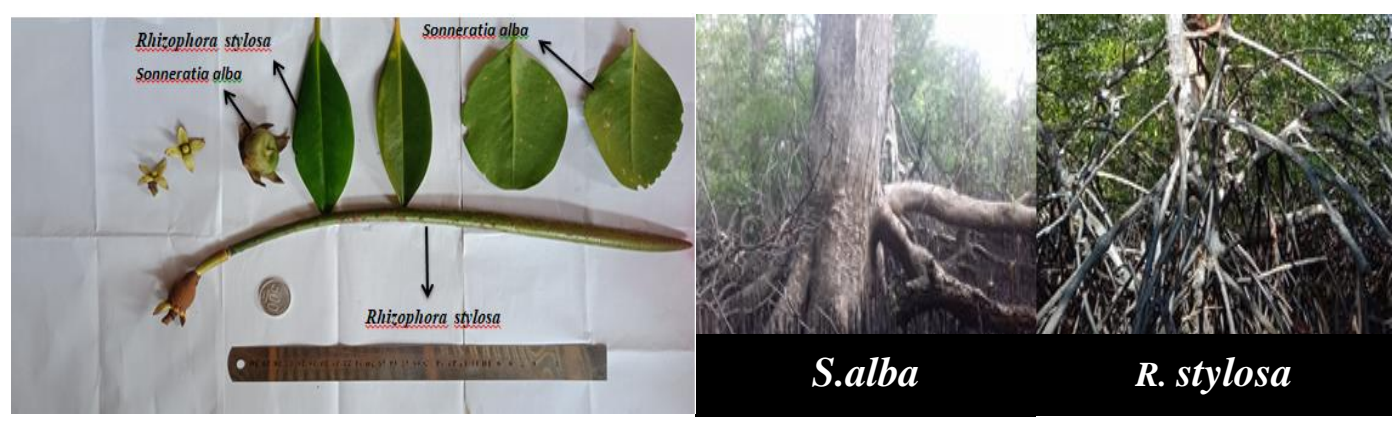

Gambar 4. Bentuk daun, akar dan buah dari spesies Rhizophora stylosa dan Sonneratia alba (Dokumen Pribadi, 2019)

\section{Kerapatan Jenis dan Kerapatan Relatif jenis}

Kerapatan jenis (Di) adalah jumlah tegakan jenis ke-i dalam suatu unit area. Sendangkan Kerapatan Relatif (RDi) adalah perbandingan antara jumlah tegakan jenis ke-i (Ni) dan total tegakan seluruh jenis $(\Sigma n)$ (Parmadi, dkk. 2016). Kerapatan jenis mangrove stasiun 1 transek $1 R$. stylosa $0.122 \mathrm{ind} / \mathrm{m}^{2}$ relatifnya $81.88 \%$, S. alba $0.027 \mathrm{ind} / \mathrm{m}^{2}$ relatifnya $18,12 \%$, transek 2 jenis $R$. stylosa $0.093 \mathrm{ind} / \mathrm{m}^{2}$ relatifnya $78.15 \%$, S. alba $0.026 \mathrm{ind} / \mathrm{m}^{2}$ relatifnya $21.85 \%$. stasiun 2 transek $1 R$. stylosa 0.108 ind $/ \mathrm{m}^{2}$ relatfnya $80.6 \%$, S. alba $0.026 \mathrm{in} / \mathrm{m}^{2}$ relatifnya $19.4 \%$, transek 2 jenis $R$. stylosa $0.091 \mathrm{ind} / \mathrm{m}^{2}$ relatifnya $77.78 \%, S$. alba $0.026 \mathrm{ind} / \mathrm{m}^{2}$ relatifnya $22.22 \%$. stasiun 3 transek 1 jenis $R$. stylosa $0.097 \mathrm{ind} / \mathrm{m}^{2}$ relatifnya $78.23 \%, S$. alba $0.027 \mathrm{ind} / \mathrm{m}^{2}$ relatinya $21.77 \%$, transek 2 jenis $R$. stylosa $0.1 \mathrm{ind} / \mathrm{m}^{2}$ relatinya $78.13 \%, \quad S$. alba 0.028 ind $/ \mathrm{m}^{2}$ relatifnya $21.88 \%$. Nilai kerapatan tertinggi terdapat di stasiun 1 transek 1 jenis $R$. stylosa dengan nilai $0.122 \mathrm{ind} / \mathrm{m}^{2}$ relatfnya $81.88 \%$ dan nilai kerapatan terendah terdapat distasiun 1 transek 2 dan stasiun 2 transek 1 dan transek 2 jenis S.alba dengan nilai $0.026 \mathrm{ind} / \mathrm{m}^{2}$ relatifnya $21.85 \%, \quad 19.4 \%$ dan $22.22 \%$.

Tingginya nilai kerapatan jenis ditentukan oleh banyaknya jumlah individu, begitu pula sebaliknya jika jumlah individunya sedikit maka nilai kerapatanya rendah. Kerapatan jenis tertinggi disebabkan oleh Tingginya Kerapatan jenis dan kerapatan relatif $R$. stylosa dikarenakan pada stasiun 1 memiliki substrat dengan jenis pasir berlumpur yang memungkinkan untuk mangrove jenis $R$. stylosa untuk dapat hidup dan berkembang dengan baik. pada umumnya Rizhophora sp dapat tumbuh dengan baik pada tanah berlumpur sampai pasir berlumpur (Parmadi, dkk. 2016).

Tabel 2. Kerapatan Jenis (Di)

\begin{tabular}{|c|c|c|r|r|r|r|}
\hline \multicolumn{7}{|c|}{ Kerapatan Jenis (Di) } \\
\hline & \multicolumn{2}{|c|}{ ST 1 ind $/ \mathrm{m}^{2}$} & \multicolumn{2}{c|}{ ST 2 ind $/ \mathrm{m}^{2}$} & \multicolumn{2}{c|}{ ST 3 ind $/ \mathrm{m}^{2}$} \\
\hline Jenis & T1 & T2 & T1 & T2 & T1 & T2 \\
\hline R. stylosa & 0.122 & 0.093 & 0.108 & 0.091 & 0.097 & 0.1 \\
\hline S. alba & 0.027 & 0.026 & 0.026 & 0.026 & 0.027 & 0.028 \\
\hline Total & 0.149 & 0.119 & 0.134 & 0.117 & 0.124 & 0.128 \\
\hline
\end{tabular}


Tabel 3. Kerapatan Relatif Jenis (RDi)

\begin{tabular}{|c|c|c|r|r|r|r|}
\hline \multicolumn{8}{|c|}{ Kerapatan Relatif Jenis (RDI) } \\
\hline ST 1 & \multicolumn{2}{c|}{ ST 2 } & \multicolumn{2}{c|}{ ST 3 } \\
\hline Jenis & T1 & \multicolumn{1}{|c|}{ T2 } & \multicolumn{1}{|c|}{ T1 } & T2 & \multicolumn{1}{l|}{ T1 } & \multicolumn{1}{|c|}{ T2 } \\
\hline R. stylosa & 81.88 & 78.15 & 80.6 & 77.78 & 78.23 & 78.13 \\
\hline S. alba & 18.12 & 21.85 & 19.4 & 22.22 & 21.77 & 21.88 \\
\hline Total & 100 & 100 & 100 & 100 & 100 & 100 \\
\hline
\end{tabular}

\section{Frekuensi Jenis dan Frekuensi Relatif jenis}

Frekuensi (Fi) adalah peluang ditemukannya suatu jenis ke-i dalam semua petak contoh yang di buat, sedangkan Frekuensi Relatif (RFi) adalah perbandingan antara frekuensi jenis $(\mathrm{Fi})$ dan total frekuensi seluruh jenis $(\Sigma \mathrm{F})$ (Parmadi, dkk. 2016). Frekuensi jenis mangrove stasiun 1 transek $1 R$. stylosa 1 relatifnya $50 \%$, S. alba 1 relatifnya $50 \%$, transek 2 jenis R.stylosa 1 relatifnya $50 \%, S$. alba 1 relatifnya $50 \%$. stasiun 2 transek $1 R$. stylosa 1 relatfnya $50 \%, S$. alba 1 relatifnya $50 \%$, transek 2 jenis $R$. stylosa 1 relatifnya $50 \%$, S. alba 1 relatifnya 50 $\%$. stasiun 3 transek 1 jenis $R$. stylosa 1 relatifnya $50 \%$, S. alba 1 relatinya $50 \%$, transek 2 jenis $R$. stylosa 1 relatinya $50 \%$, S. alba 1 relatifnya 50 $\%$. Nilai frekuensi tertinggi terdapat di semua stasiun dan semua transek pada kedua jenis mangrove dengan nilai 1 relatifnya $50 \%$ dan nilai frekuensi terendah tidak ditemukan dikarenakan nila frekuensi kedua jenis di setiap stasiun memiliki nilai yang sama yaitu 1 relatifnya $50 \%$ (tabel 4 dan 5)

Secara keseluruhan jenis R.stylosa dan S.alba ditemukan pada setiap stasiun pengamatan. Hal ini menunjukan bahwa ke dua jenis ini memiliki penyebaran jenis dan keberadaan yang tinggi jika dibandingkan dengan jenis yang lainnya. Menurut Poedjirahajoe, 1966 dalam Iskandar, dkk. 2019 substrat jenis lempung berpasir atau berlumpur memang merupakan substrat yang sangat cocok untuk tempat tumbuhnya jenis R.stylosa. Juga menurut Arief, 2003 dalam Iskandar.

Tabel 4. Frekuensi Jenis (Fi)

\begin{tabular}{|c|c|c|c|c|c|c|}
\hline \multicolumn{8}{|c|}{ Frekuensi Jenis (Fi) } \\
\hline & \multicolumn{3}{|c|}{ ST 1 } & \multicolumn{2}{c|}{ ST 2 } & \multicolumn{2}{c|}{ ST 3 } \\
\hline Jenis & T1 & T2 & T1 & T2 & T1 & T2 \\
\hline R. stylosa & 1 & 1 & 1 & 1 & 1 & 1 \\
\hline S. alba & 1 & 1 & 1 & 1 & 1 & 1 \\
\hline Total & 2 & 2 & 2 & 2 & 2 & 2 \\
\hline
\end{tabular}


Tabel 5. Frekuensi Relatif Jenis (RFi)

\begin{tabular}{|c|c|c|r|r|r|r|}
\hline \multicolumn{1}{|c|}{ Ferekuensi Relatif jenis (RFi) } \\
\hline & \multicolumn{2}{|c|}{ ST 1 } & \multicolumn{2}{c|}{ ST 2 } & \multicolumn{2}{c|}{ ST 3 } \\
\hline & T1 & T2 & T1 & T2 & T1 & T2 \\
\hline Jenis & 50 & 50 & 50 & 50 & 50 & 50 \\
\hline R. stylosa & 50 & 50 & 50 & 50 & 50 & 50 \\
\hline S. alba & 100 & 100 & 100 & 100 & 100 & 100 \\
\hline Total &
\end{tabular}

\section{Penutupan Jenis dan Penutupan Relatif Jenis}

Penutupan jenis ( $\mathrm{Ci}$ ) adalah luas penutupan jenis ke-i dalam suatu area sedangkan Penutupan relatif $(\mathrm{RCi})$ adalah perbandingan antara luas area penutupan jenis ke-i (Ci) dan total luas penutupan untuk seluruh jenis $(\Sigma C)$ (Parmadi, $d k k$. 2016). Penutupan jenis mangrove stasiun 1 transek $1 R$. stylosa $1.75 \mathrm{~m}^{2}$ relatifnya $50.24 \%$, S. alba $1.73 \mathrm{~m}^{2}$ relatifnya $49.76 \%$, transek 2 jenis $R$. stylosa $1.75 \mathrm{~m}^{2}$ relatifnya $50.84 \%, S$. alba $1.70 \mathrm{~m}^{2}$ relatifnya $49.16 \%$. stasiun 2 transek $1 R$. stylosa $1.83 \mathrm{~m}^{2}$ relatfnya $50.83 \%$, S. alba $1.77 \mathrm{~m}^{2}$ relatifnya $49.17 \%$, transek 2 jenis $R$. stylosa $1.53 \mathrm{~m}^{2}$ relatifnya $50.88 \%, S$. alba $1.47 \mathrm{~m}^{2}$ relatifnya $49.12 \%$. stasiun 3 transek 1 jenis $R$. stylosa $1.77 \mathrm{~m}^{2}$ relatifnya $49.97 \%$, S. alba
$1.78 \mathrm{~m}^{2}$ relatinya $50.03 \%$, transek 2 jenis $R$. stylosa $1.83 \mathrm{~m}^{2}$ relatinya $50.18 \%$, S. alba $1.82 \mathrm{~m}^{2}$ relatifnya $49.82 \%$. Nilai penutupan tertinggi terdapat di stasiun 2 transek 1 jenis $R$. stylosa dan stasiun 3 transek 2 jenis R.stylosa dengan nilai $1.83 \mathrm{~m}^{2}$ relatfnya $50.18 \%$ dan nilai penutupan terendah terdapat distasiun 2 transek 2 jenis $S$. alba dengan nilai $1.47 \mathrm{~m}^{2}$ relatifnya $49.12 \%$ ( tabel 6 dan 7 ).

Kondisi hutan mangrove yang berhadapan langsung dengan laut sehingga mendapatkan pasang surut air laut sangat mendukung jenis tersebut untuk tumbuh. Selanjutnya Faktor yang mempengaruhi rendahnya nilai penutupan jenis karena adanya kondisi mangrove yang heterogen (Sofian $d k k$., 2012).

Tabel 6. Penutupan jenis (Ci)

\begin{tabular}{|c|c|c|r|r|r|r|}
\hline \multicolumn{7}{|c|}{ Penutupan Jenis (Ci) } \\
\hline & \multicolumn{3}{|c|}{ ST 1 } & \multicolumn{2}{c|}{ ST 2 } & \multicolumn{2}{c|}{ ST 3 } \\
\hline Jenis & T1 & \multicolumn{1}{c|}{ T2 } & T1 & T2 & T1 & T2 \\
\hline R. stylosa & 1.75 & 1.75 & 1.83 & 1.53 & 1.77 & 1.83 \\
\hline S. alba & 1.73 & 1.70 & 1.77 & 1.47 & 1.78 & 1.82 \\
\hline Total & 3.48 & 3.45 & 3.60 & 3.00 & 3.55 & 3.66 \\
\hline
\end{tabular}

Tabel 7. Penutupan Relatif Jenis (RCi)

\begin{tabular}{|c|c|c|r|r|r|r|}
\hline \multicolumn{7}{|c|}{ Penutupan Relatif Jenis (Rci) } \\
\hline & \multicolumn{2}{|c|}{ ST 1 } & \multicolumn{2}{c|}{ ST 2 } & \multicolumn{2}{c|}{ ST 3 } \\
\hline Jenis & T1 & \multicolumn{1}{c|}{ T2 } & T1 & T2 & T1 & T2 \\
\hline R. stylosa & 50.24 & 50.84 & 50.83 & 50.88 & 49.97 & 50.18 \\
\hline S. alba & 49.76 & 49.16 & 49.17 & 49.12 & 50.03 & 49.82 \\
\hline Total & 100 & 100 & 100 & 100 & 100 & 100 \\
\hline
\end{tabular}




\section{Indeks Nilai Penting}

Indeks Nilai Penting adalah jumlah nilai kerapatan relatif jenis (RDi), frekuensi relatif jenis (RFi), dan penutupan relatif jenis (RCi). Nilai penting suatu jenis berkisar antara $0 \%$ - 300\%. Nilai penting ini memberikan suatu gambaran mengenai pengaruh atau peranan suatu jenis tumbuhan mangrove dalam komunitas mangrove (Parmadi., dkk. 2016). Indeks Nilai Penting (INP) Menurut Indriyanto, 2006 dalam Bacmid, dkk. 2019 bahwa spesies-spesies yang dominan dalam suatu komunitas tumbuhan memiliki indeks nilai penting yang tinggi, sehingga spesies yang paling dominan memiliki indeks nilai penting yang paling besar. Indeks nilai penting jenis mangrove pada setiap lokasi adalah 300 , hal ini menunjukan peran setiap spesies mangrove memiliki pengaruh yang besar, selain itu juga berpengaruh terhadap petumbuhan mangrove dalam sutu komunitas. Eksploitasi mangrove, habitat yang cocok dan kondisi perairan yang stabil adalah faktor-faktor yang dapat mempengaruhi besarnya nilai penting. Indeks Nilai Penting mangrove stasiun 1 transek $1 R$. stylosa $182.12 \%$, S. alba $117.88 \%$, transek 2 jenis R. stylosa $178.99 \%$, S. alba $121.01 \%$. stasiun 2 transek 1 R. stylosa $181.43 \%, \quad S$. alba $118.57 \%$,

transek 2 jenis $R$. stylosa $178.65 \%$, S. alba $121.35 \%$. stasiun 3 transek 1 jenis $R$. stylosa $178.19 \%$, S. alba $121.81 \%$, transek 2 jenis $R$. stylosa
$178.31 \%$, S. alba $121.69 \%$. Indeks Nilai Penting tertinggi terdapat di stasiun 1 transek 1 jenis $R$. stylosa dengan nilai $182.12 \%$ dan Indeks Nilai Penting terendah terdapat distasiun 1 transek 1 jenis $S$. alba dengan nilai $117.88 \%$ (tabel 8) Bila dibandingkan dengan beberapa penelitian yang pernah dilakukan, seperti Takarendehang, dkk. 2018 mangrove yang berada di Desa Lansa memiliki indeks nilai penting yang didominasi oleh jenis $R$. stylosa dengan nilai INP 179,75, Jacobs, dkk.2019 mangrove yang berda di Desa Lamanggo dan Desa Tope, Kecamatan Biaro, Kabupaten Kepulauan Siau, Tagulandang, Biaro memiliki INP yang dominan terdapat pada jenis $R$. apiculata yaitu sebesar 100.59, Bacmid, dkk. 2019, mangrove yang berada di Kecamatan Bunaken Bagian Timur, Kelurahan Alung Banua yang memliki indeks nilai penting yang terdapat pada lokasi penelitian yaitu jenis S.alba 300, Anthoni, dkk. 2017, mangrove yang memiliki indeks nilai penting yang terdapat di pesisr Desa Molas memiliki indeks nilai penting pada lokasi penelitian yaitu jenis S.alba 178.09. Iskandar, dkk. 2019, mangrove yang memmeliki indek nilai penting yang terdapat di Desa Arakan memiliki indeks nilai penting pada lokasi penelitian yaitu jenis R.stylosa 292.935. Dari ketiga hasil penelitian di atas bila dibandingkan dengan hasil penelitian ini, maka indeks nilai penting pada penelitian ini masih di kategorikan sangat masih rendah. 
Tabel 8. Indeks Nilai Penting (INP)

\begin{tabular}{|c|c|c|r|r|r|r|}
\hline \multicolumn{7}{|c|}{ INDEKS NILAI PENTING (INP) } \\
\hline ST 1 & \multicolumn{2}{|c|}{ ST 2 } & \multicolumn{2}{c|}{ ST 3 } \\
\hline Jenis & T1 & \multicolumn{1}{|c|}{ T2 } & T1 & T2 & T1 & T2 \\
\hline R. stylosa & 182.12 & 178.99 & 181.43 & 178.65 & 178.19 & 178.31 \\
\hline s. alba & 117.88 & 121.01 & 118.57 & 121.35 & 121.81 & 121.69 \\
\hline Total & 300 & 300 & 300 & 300 & 300 & 300 \\
\hline
\end{tabular}

\section{KESIMPULAN DAN SARAN}

\section{Kesimpulan}

1. Dari hasil penelitian yang dilakukan di Desa Lesah, Kecamatan Tagulandang, Kabupaten Sitaro, setelah diidentifikasdi mangrove di Desa Lesah terdapat 2 jenis mangrove, yang terdiri dari, Rhizophora stylosa dan Sonneratia alba. Dari hasil penelitian diperoleh hasil total nilai struktur komunitas mangrove kategori kerapatan jenis, kerapatan relatif jenis, frekuensi jenis, frekuensi relatif jenis, penutupan jenis, penutupan relatif jenis, indeks nilai penting disetiap stasiun menunjukan bahwa nilai tertinggi yang mendominasi adalah jenis Rhizophora stylosa. diduga bahwa pada daerah ini memiliki habitat yang cocok, selain itu juga dipengaruhi oleh rendahnya kegiatan pembabatan mangrove dan kemampuan beradaptasi dengan lingkungan.

2. Hasil analisis data indeks ekologi mangrove (Nilai indeks keanekaragaman dan dominasi) jenis Rhizophora stylosa dan
Sonneratia alba dari tiga stasiun menujukan bahwa nilai tertinggi terdapat pada jenis Rhizophora stylosa.

\section{Saran}

1. Pengelolaan hutan mangrove perlu disosialisasikan kepada beberapa instansi terkait dan masyarakat sekitar yang berada di Desa Lesah, disertai kegiatan pengawasan, dan pengendalian langsung dilapangan.

2. Identifikasi jenis struktur komunitas mangrove yang terdapat di Desa Lesah sebaiknya dilakukan secara berkelanjutan.

\section{DAFTAR PUSTAKA}

Agustini, N.T., Ta'alidin, Z., Purnama, D. 2016. Struktur Komunitas Mangrove Di Desa Kahyapu Pulau Enggano. Jurnal Enggano Vol 1. No. 1.

Akbar, N.S., Umalekhoa, Marus, I., Haji I., S. Abdullah., F.S. Ibrahim dan A. Kahar., Ahmad, M., Ibrahim, A., I. 
Tahir. 2017. Struktur Komunitas Hutan Mangrove $\mathrm{Di}$ Teluk Dodinga, Kabupaten Halmahera Barat Provinsi Maluku Utara. Jurnal Enggano Vol 2 No. 1 : 7889

Iskandar, A.O.T., Schaduw, J.N.W., Rumampung, N.D.C. 2019. Kajian Kesesuaian Lahan Ekowisata Mangrove Di Desa Arakan Kabupaten Minahasa Selatan Sulawesi Utara. Jurnal Pesisir dan Laut Tropis. Vol. 7 No. 1

Anthoni, A., Schaduw, J.N.W., Sondak, C.F.A. 2017. Persentase Tutupan dan Struktur Komunitas Mangrove Di Sepanjang Pesisir Taman Nasional Bunaken Bagian Utara. Jurnal Pesisir dan Laut Tropis. Vol 2 No.1 : 13-21

Bengen, D.G 2000. Sinopsis Ekositem dan Sumberdaya Wilayah Pesisir.Pusat Kajian Sumberdaya Pesisir dan Lautan IPB. Hal. 1:2.

Bacmid, N.K., Schaduw, J.N.W., Warouw, V. 2019. Kajian Kesesuaian Lahan Ekowisata Mangrove Dimensi Ekologi ( Kasus Pada Pulau Bunaken Bagian Timur, Kelurahan Alung Banua, Kecamatan Bunaken Kepulauan, Kota Manado). Jurnal Pesisir dan Laut Tropis.Vol 7. No. 2
Dharmawan .I.E. dan Pramudji. 2014. Panduan Monitoring Status Ekosistem Mangrove. Pusat Penelitian OseanografiLIPI. Hal. 1

Djamaludin R. 2018. Mangrove Biologi, Ekologi, Rehabilitas, dan Konservasi. Unsrat Press, Hal. 41:42.

Fitriadi, Gunawan, T., Rijanta. 2015. Peran Pemerintah Dan Partisipasi Masyarakat Dalam Rehabilitasi Hutan Mangrove: Kasus Di Kecamatan Pemangkat Kabupaten Sambas Kalimantan Barat. Manusia dun Lingkungan, Vol 12 No.3

Iskandar, A.T.O., Schaduw, J.N.W., Rumampuk, D.C.N., Sondak, C.F.A., Warouw, V., Rondonuwu, A. 2019. Kajian Kesesuaian Lahan Ekowisata Mangrove Di Desa Arakan Kabupaten Minahasa Selatan Sulawesi Utara. Jurnal Pesisir Laut dan Tropis. Vol 7 No. 1

Jacobs, R., Kusen, J.D., Sondak, C.F.A., Boneka, F.B., Warouw, V., Mingkid, W.M. 2019. Struktur Komunitas mangrove di Desa Lamanggo dan Desa Tope, Kecamatan Biaro, Kabupaten Kepulauan Siau, Tagulandang, Biaro. Jurnal Pesir dan Laut Tropis. Vol 1 No 1. 
Lahabu, Y., Schaduw J.N.W., Windarto, A.B. 2015. Kondisi Ekologi Mangrove Di Pulau Mantehage Kecamatan Wori Kabupaten Minahasa Utara Provinsi Sulawesi Utara. Jurnal Pesisir dan Laut Tropis. Vol 2 No. 1

Noor, Y,. Khazali.M.., I.N.N. Suryadiputra. 2006. Panduan Pengenalan Mangrove Di Indonesia. PHKA/IP, Bogor.

Mayor,T., I.E Herny., Simbala., Koneri, R. 2017. Biodiversitas Mangrove di Pulau Mansuar Kabupaten Raja Ampat Provinsi Papua Barat. Jurnal Bioslogos. Vol. 7, No. 2

Paputungan, Z., Wonggo, D., Kaseger, E.B. 2017. Uji Fitokimia dan Aktivitas Antioksidan Buah Mangrove Sonneratia alba di Desa Nunuk Kecamatan Pinolosian Kabupaten Bolaang Mongondow Selatan. Jurnal Media Teknologi Hasil perikanan. Vol 5, No. 3

Parmadi, E.H. JC., Dewiyanti, I., Karina, S. 2016. Indeks Nilai Penting Vegetasi Mangrove Di Kawasan Kuala Idi, Kabupaten Aceh Timur. Jurnal IImiah Mahasiswa Kelautan dan Perikanan Unsyiah. Vol 1 No. $1: 82-95$.
Senoaji, G., dan Hidayat, M.F. Peranan Ekosistem Mangrove Di Pesisir Kota Bengkulu Dalam Mitigasi Pemanasan Global Melalui Penyimpanan Karbon. J.Manusia Dan Lingkungan. Vol. 23, No. 3

Saenger, P., E.J. Hegerl., J.D.S. Davie. 1983. Global Status of Mangrove Ecosystems. IUCN Commission on Ecology Papers No. 3, 88 Hal.

Sasauw, J., Kusen, D.J., Schaduw, J.N.W. 2016. Struktur Komunitas Mangrove Di Kelurahan Tongkaina Manado. Jurnal Pesisir dan Laut Tropis. Vol 2 No. 1

Samiyarsih, S., Brata.T.S, Juwarno.2016 Karakter Antomi Daun Tumbuhan Mangrove Akibat Pencemaran di Hutan Mangrove Kabupaten Cilacap. Biosfera Vol 33 No. 1: 31-36

Schaduw, J.N.W 2015. Keberlanjutan Pengelolaan Ekosistem Mangrove Pulau Mantehage, Kecamatan Wori, Kabupaten Minahasa Utara Provinsi Sulawesi Utara. Jurnal LPPM Bidang Sains dan Teknologi. Vol 2 No. 2

Schaduw, J.N.W 2015. Bioekologi Mangrove Daerah Perlindungan Laut Bebasis Masyarakat Desa Blongko Kecamatan Sinonsayang 
Kabupaten Minahasa

Selatan Provinsi Sulawesi

Utara. Jurnal LPPM Bidang

Sains dan Teknologi. Vol 2

No. 1

Sulistiyowati, H. 2009.

Biodiversitas Mangrove di

Cagar Alam Pulau Sempu.

Jurnal Saintek, 8(1) : 59-64.

Sukardjo, S. 1984. Ekosistem

Mangrove. Oseana. Vol 9,

No. $4: 102-115$.

Sofian A, Harahap dan Marsoedi.2012. Kondisi dan ManfaatLangsung EkosistemHutan Mangrove
Desa Penunggul

Kecamatan Nguling

Kabupaten Pasuruan

Jurnal El-Hayah. Vol 2 No.

$2: 56-63$

Takarendehang, R., Sondak, C.F.A. Kondisi Ekologi Dan Nilai Manfaat Hutan Mangrove Di Desa Lansa, Kecamatan Wori, Kabupaten Minahasa Utara. Jurnal Pesisir dan Laut Tropis. Vol. 2 No. 1

Wardhani, M.K. 2011. Kawasan Konservasi Mangrove: Suatu Potensi Ekowisata. Jurnal Kelautan, Vol 4 No.1 